\title{
After Sales Service For Smartphone Iphone To Customer Loyalty
}

\author{
Fachri Hussein ${ }^{1}$, Hartelina ${ }^{2}$, \\ Universitas Singaperbangsa Karawang \\ e-mail: 1610631020141@ student.unsika.ac.id, hartelina.ekonomi@fe.unsika.ac.id
}

\section{To cite this document :}

Hussein, F., \& Hartelina, H. (2021). After Sales Service For Smartphone Iphone To Customer Loyalty. Aptisi Transactions on Management (ATM), 5(1), 62-72.

DOI :

https://doi.org/10.33050/atm.v5i1.1436
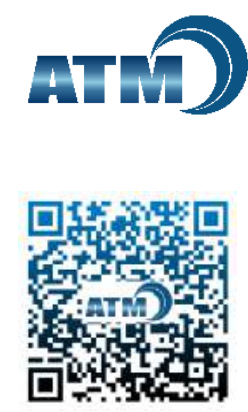

Author Notification

12 October 2020

Final Revised

5 January 2021

Published

15 January 2021

\begin{abstract}
Apple Inc. company is a big company but that doesn't mean Apple can underestimate newcomers. This iPhone smartphone sold in the city of Karawang has decreased sales in 2019 every month. The variables used are after-sales service, customer loyalty, value co-creation. The problem in this research is to find out how much influence after sales service has on the value cocreation of the iPhone smartphone. To find out how much influence value creation has on customer loyalty of iPhone smartphones. To find out how much influence after sales service has on customer loyalty through the co-creation of the iPhone smartphone. This research uses a descriptive approach, and verification. A sample of 100 respondents who are iPhone smartphone users using purposive sampling technique, the result is that after-sales service and co-creation value have a strong enough effect, amounting to $47.1 \%$. Meanwhile, Value Co-Creation has a direct effect of $50.9 \%$. The indirect effect of after-sales service on customer loyalty is $18.8 \%$.
\end{abstract}

\section{Keywords: After Sales Service, Value Co-Creation, Customer Loyalty,iPhone}

\section{Introduction}

Smartphones are no longer used as a means of communication but are also a social and work necessity [1] . In developing and developing countries, many people have adopted the use of cell phones in the learning process. The young generation now has high curiosity so that they can easily keep up with the changing times which have an impact on high knowledge of technology. With a variety of adequate specifications at a price equal to quality, coupled with the image as a high-end cellphone, people are increasingly enthusiastic about being able to have a modified smartphone as attractive as possible [2].

The iPhone is one of the products of the exposed communication tool company namely Apple Inc. This iPhone smartphone is included in the category of sophisticated communication tools, and also the iPhone has its own phone operating system known as Apple's iOS or 'iPhone OS "(Source Wikipedia.org accessed on May 4, 2020 at 20.25 WIB). The number of smartphone brands on the market makes competition between companies even tighter. Companies need to study and identify the factors that will lead the company to success [3]. Apple is one company that has succeeded in creating a strong brand image in the minds of customers. This is evident from the high sales growth of Apple's smartphone products, namely the iPhone. There was so much interest in smartphone products created by Apple even before the product was launched [4]. Having a price that is quite expensive for certain circles does not deny that iPhone smartphones are still in demand, even Indonesia itself has an online community called iDevice Indonesia as an association of iPhone smartphone users and also as a form of discussion forum among iPhone users or new users who will use the iPhone.

Karawang Regency has several shopping centers, be it traditional markets or malls, in the city of Karawang it has 4 malls, one of which is Resinda Park Mall, which offers many products such as bags, food, shoe clothes to electronics stores. With the existence of a shopping center it 
is an attraction for the community itself, and provides options for the community, especially in the smartphone sector. Lots of smartphone outlets in the city of Karawang, be it Samsung, Oppo, Vivo and iPhone. Moreover, Karawang has iBox at Resinda Park Mall as a special store selling all Appe Inc products, and this makes it easier for iPhone users to find accessories or to repurchase iPhone products. The following is the sales data for the iPhone iBox Store at Resinda Park Mall:

Table 1

IPhone Smartphone Sales Data at iBox Store Resinda Park Mall

\begin{tabular}{|l|c|}
\hline Month & Sales \\
\hline January & 714 \\
\hline February & 634 \\
\hline March & 1469 \\
\hline April & 1222 \\
\hline May & 1853 \\
\hline June & 1297 \\
\hline July & 1273 \\
\hline August & 1272 \\
\hline September & 1359 \\
\hline October & 1049 \\
\hline November & 1049 \\
\hline December & 3752 \\
\hline
\end{tabular}

1. Table shows that the sales data on the smartphone iPhone on iBox Store Resinda Park Mall is fluktuaktif. Sales on iPhone smartphones have increased quite well in January December. In December, the iBox Store received the highest number, namely 3,753. This is because the enthusiasts for the iPhone 11 have increased at the end of 2019 and at the beginning of 2020. The enthusiasts of the iPhone 11 are not only from the Karawang community but also from the people of Subang and Purwakarta cities.

Andi Aryanto as Store Head of iBox Store Resinda Park Mall, said that in early 2019 the most popular iPhone sales were the iPhone 7+, this was because the iPhone 7+ had decreased in price so that the Karawang community had an interest in buying the iPhone $7+$. The iBox store Resinda Park Mall does not receive service for damage, but the iBox Store receives a check on the condition of a damaged iPhone smartphone. Service will be carried out at the center of iBox itself with a delivery period of approximately 1 week or 10 days

One of the factors of business success in facing highly competitive competition is customer loyalty. Customer loyalty enables companies to develop long-term relationships with consumers and are not limited to buying and selling. Tjiptono in his writing [5] consumer loyalty is a customer commitment to a brand, store, or supplier based on very positive traits in longterm purchases. Consumer loyalty is an emotional relationship between consumers and companies based on the consumer's love for the products and services offered and provided with the desire to make repeat purchases. [6]. Customer loyalty is a customer who keeps making repeated purchases for several reasons and the customer has no plans to replace the product with a competing product. Hurriyati in his writing [7] states that customer loyalty (customer loyalty) is a very important boost to create sales.

To find out customer loyalty on iPhone Smartphones, researchers distributed questionnaires to 30 respondents with the following results: 


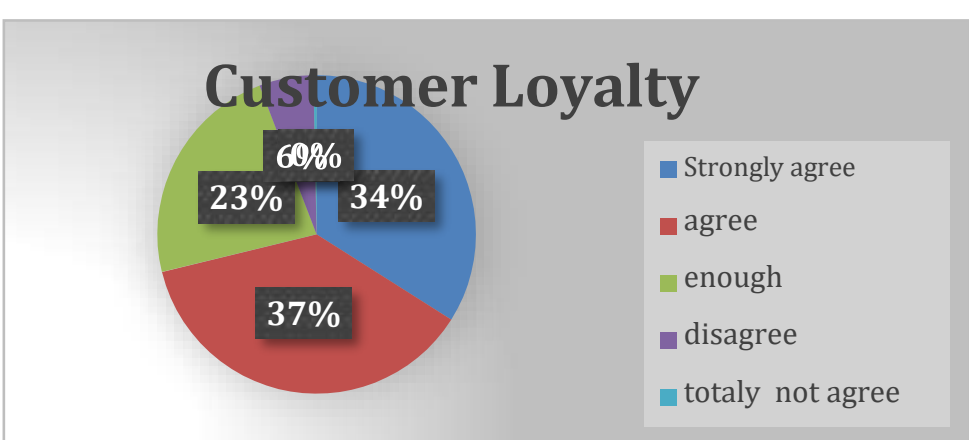

Figure 1. Pre-Survey Results Diagram of Customer Loyalty Variables

Based on Figure 1.2 the results of the pre-survey on 30 respondents by providing a statement regarding customer loyalty to iPhone smartphone users in Karawang Regency. Only $37 \%$ stated that they agreed with customer loyalty, while $23 \%$ of respondents chose sufficient as the level of customer loyalty on iPhone smartphones. This can be caused by several factors, for example, the level of loyalty to the product, which means that smartphone users have not planned to make repeat purchases, also the level of plans to buy other line products, which means that consumers do not have plans to buy product lines from Apple Inc. and the level of refusal to use the product. competitors, the level of enthusiasm to invite others to use the product. This is the task for Apple Inc to increase the appeal of the public and users to be more loyal to these products and make repeated purchases,

The effect of after-sales service on customer loyalty is also very important, because with the after-sales service provided by the company to consumers, it indicates that the company really considers the satisfaction and loyalty of these customers. with the services provided as a benchmark for re-purchase of a product. If a company does not provide the maximum possible after-sales service, this will make users switch to other products, resulting in decreased sales. Satisfaction and loyalty are not mutually exclusive. It is further stated that it is possible that customers will be loyal without having to be very satisfied (for example, when there are several other options) and customers will be very satisfied, but not loyal (for example, when many alternatives are available) [8].

To find out after sales service on iPhone Smartphones, researchers distributed questionnaires to 30 respondents with the following results:

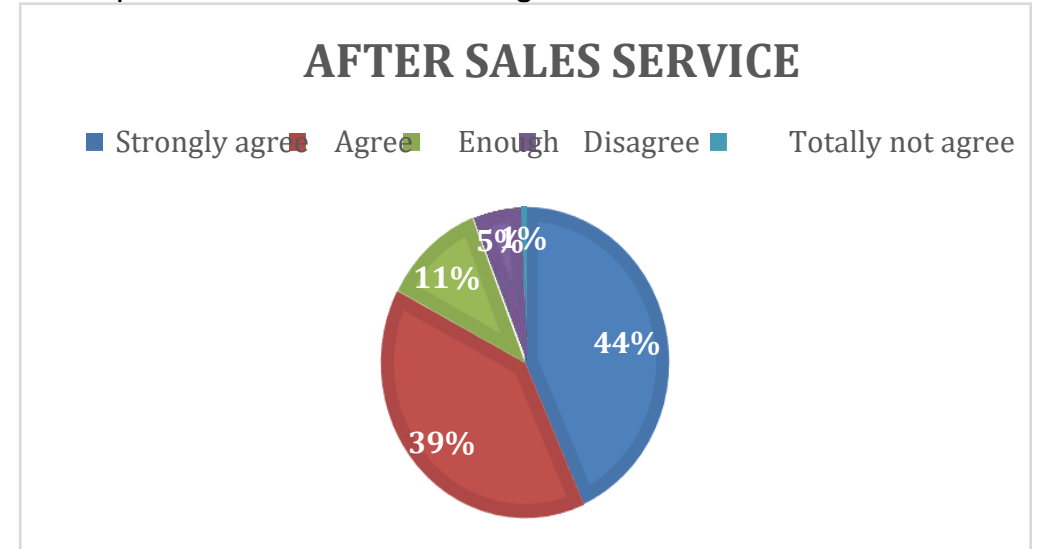

Figure 2. Pre-Survey Result Diagram of After Sales Service Variables

Based on Figure 1.3 the results of the pre-survey on 30 respondents by providing a statement regarding after-sales service to iPhone smartphone users in Karawang Regency. Only $46 \%$ stated that they agreed with the after-sales service provided, while $25 \%$ of respondents chose sufficient as the level of after-sales service on iPhone smartphones. This can be caused by several factors, for example, the level of warranty is easy to claim and the rate of return of the warranty if there is still damage. This makes customers think again before deciding to use an iPhone smartphone, because not only thinking about the quality of a product, after sales service is also very important for consumers. Because with good after-sales service it will give satisfaction to users and even users will make repeated purchases. Tjiptono's after- 
sales service in his writing [9] is a service provided by producers to consumers after the consumer buys a product from the company. After-sales service is a service received by customers after making a purchase in an effort to maintain customer trust. After-sales service can be in the form of repair (service), warranty and spare parts [10]. Companies are currently competing to provide excellent service, one of which is after-sales service to help consumers and give trust to the company. After-sales service can also be a weapon for companies to fight competitors who have not implemented this after-sales service. Kotler in his writing [11] explains that after-sales service is to provide the best support for companies to provide after-sales service, most companies move in several stages. A company can satisfy its customers or consumers after buying goods or services from the company. Fandy Tjiptono in writing [12], there are several alternative strategies that companies can do to reduce the possibility of uncertainty, namely by providing after-sales services, namely providing guarantees to reduce consumer perceptions of purchase risks, repair services, and provision of replacement parts. Ganon in [8] after-sales service is a service provided to customers after the customer purchases a product. The dimensions of after-sales service consist of: 1) Guarantee 2) Availability of spare parts 3) Service technicians.

Apart from the after-sales service side, customer loyalty of iPhone smartphones is also influenced by value co-creation, this is based on research [13] Companies must be firm in creating joint services with users, it's necessary for them to be involved in an effective long-term relationship related to the services provided. Taking into account the wishes, criticisms and suggestions from consumers for Apple Inc. this also determines the success of Apple products, especially in the smartphone field. The meaning of the value of Co-Creation is the interaction between the company and the customer. Companies have found good working with consumers, so that consumers can become value creation agents, which can lead to a shared value creation trend, indicating that companies doing value co-creation can create new trends in order to survive in the competition. in the field of communication [14] Loyal consumers can help the company by providing input or criticism of a product to improve its quality or create new value creations (value co-creation) as product innovation.

To find out value co-creation on iPhone Smartphones, researchers distributed questionnaires to 30 respondents with the following results:

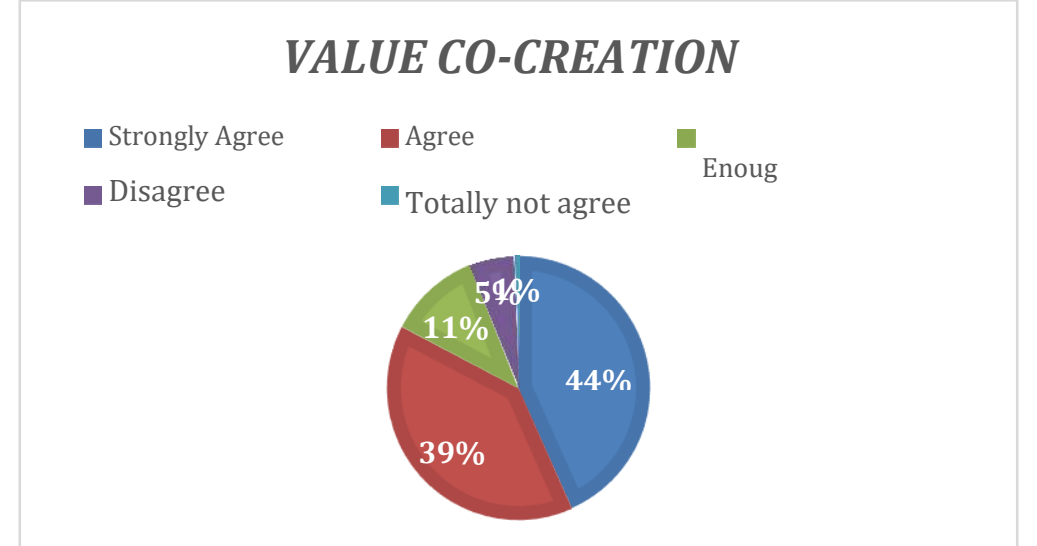

Figure 2.Pre-Survey Result Diagram of Value Co-Creation Variables

Based on Figure 3 the results of the pre-survey on 30 respondents by providing a statement regarding value co-creation on iPhone smartphone users in Karawang Regency. Only $44 \%$ stated that they strongly agreed with Apple Inc's value co-creation, while $11 \%$ of respondents chose sufficient as the level of value co-creation on iPhone smartphones. This could be due to several factors, such as the level of interest in the new iPhone product, respondents think that every time Apple Inc releases its new product in the smartphone sector, respondents are quite interested, but respondents prefer to stay with the iPhone products that are currently used. Also the level of intensity of customers in seeking product information. This makes respondents think that every time Apple Inc releases a new series in its smartphone sector, some customers do not immediately buy the product, one of which is that the iPhone has a fairly expensive price range so that this makes consumers think again in re-purchasing iPhone products. Vargo and Lusch, in their writing [15] Customer skills and knowledge influence 
the value creation process. Thus, value is a joint function of supplier and customer actions and is always the result of co-creation Value co-creation according to Gro"nroos [16] is a joint process to produce new, shared, collaborative, concurrent value values, both materila $\mathrm{dn}$ symboli. There is an ongoing debate about the difference between co-creation and coproduction and the needs between them.

Based on the above, the author wants to research after-sales service, value co-creation and customer loyalty so that the title of this study is " The Effect of After-Sales Service on Customer Loyalty with Value Co-Creation as Intervening on iPhone Smartphones (Survey on the Online Community iDevice Indonesia) ".

\section{Research Method}

In carrying out the compilation process there are several things that must be considered, including what methods are used to solve the problems in this study. The method used by researchers is a quantitative method with descriptive and verification approaches. The population used in this study are countless smartphone users in online communities. The calculation in the test uses the formula Hair et al [17]. The sampling technique was purposive sampling technique. in collecting data using techniques using looking at, interview and questionnaires. The data analysis using use a scale range, path analysis.

\section{Literature review}

1. Based on research made by (Eduardo Luiz Braun \& Borchardt, 2014) [18] with the title Value co-creation in maintenance services: case study in the mechanical industry Value co-creation has a positive impact on customerization capabilities, but also directly impacts on service .

2. Based on research conducted by (Ashfaq, 2019) [19] entitled After Sale Service, Consumer Satisfaction and Loyalty in Telecom Sector. The results show that all dimensions of after-sales service (ie, delivery, installation, warranty, online support, grading, and complaints) directly and indirectly affect loyalty through satisfaction. Satisfaction has a direct positive influence on loyalty, and partly mediates the effect of after-sales service on loyalty as well

3. Based on research made by (Zuhdi, 2018) [20] entitled The Effect of After-Sales Service on Customer Loyalty Case Studies at Pt.Astra Internasional Tbk Bogor Branch. Based on the findings of the after-sales service study, it is very important to satisfy and gain customer loyalty, especially in service sector organizations.

4. Based on research conducted by (Maduka, 2016) [13] entitled Effects of Customer Value Co-Creation on Customer Loyalty in the Nigerian Service Industry. Companies must firmly create joint services with customers, it is important for them to engage in interactive dialogue with customers, communicate effectively to customers about service offerings

5. Based on research made by (Cossío-silva \& Revilla-camacho, 2016) [15] entitled Value co-creation and customer loyalty. There is a positive relationship between Value Co Creation and Customer Loyalty

\section{Results and Analysis}

In the results of this test, it was found that the results of the validity and reliability testing as well as the classical assumption test were free from normality problems, multicollinearity. Thus the test is suitable for use in testing the hypothesis of this study: In path analysis, the relationship between independent variables which has a significant correlation can be calculated the amount of direct influence or indirect effect. The following is the relationship between the two variables described in table 1 as follows :

\begin{tabular}{|c|c|c|c|c|}
\hline \multicolumn{5}{|c|}{$\begin{array}{l}\text { Table } 2 \\
\text { Model Summary }\end{array}$} \\
\hline \multicolumn{5}{|c|}{ Model Summary } \\
\hline Model & $\mathrm{R}$ & $\begin{array}{c}\mathrm{R} \\
\text { Square }\end{array}$ & $\begin{array}{l}\text { Adjusted R } \\
\text { Square }\end{array}$ & $\begin{array}{l}\text { Std. Error of } \\
\text { the Estimate }\end{array}$ \\
\hline 1 & $.471^{\mathrm{a}}$ & .222 & 214 & 6.09582 \\
\hline \multicolumn{5}{|c|}{ a. Predictors: (Constant), } \\
\hline
\end{tabular}

Source: Data Processing Results, 2020 
Source: Data Processing Results, 2020

From the Model Summary table data, it is known that the magnitude of $R$ Square $\llbracket(R \rrbracket \wedge$

2) is 0.222 . This figure is used to see the magnitude of the influence of the After Sales Service

$(\mathrm{X})$ variable on Value Co-Creation $(\mathrm{Y})$ by calculating the coefficient of determination $(\mathrm{KD})$ with the following formula:

$\mathrm{KD}=\mathrm{R} 2 \times 100 \% \mathrm{KD}=0.222 \times 100 \%$

$\mathrm{KD}=22.2 \%$

The amount of the path coefficient for other variables outside the research that affects it can be calculated using the following formula:

$$
\begin{aligned}
\mathrm{P} \text { Y } 11 & =\sqrt{ } 1-\mathrm{R} 2 \mathrm{XY} \\
& =\sqrt{ } 1-0,222 \\
& =0.778
\end{aligned}
$$

\begin{tabular}{|c|c|c|c|c|c|c|}
\hline \multicolumn{7}{|c|}{ Coefficients $^{a}$} \\
\hline \multirow{2}{*}{\multicolumn{2}{|c|}{ Model }} & \multicolumn{2}{|c|}{$\begin{array}{c}\text { Unstandardized } \\
\text { Coefficients }\end{array}$} & \multirow{2}{*}{$\begin{array}{c}\text { Standardized } \\
\text { Coefficients } \\
\text { Beta } \\
\end{array}$} & \multirow[t]{2}{*}{$t$} & \multirow[t]{2}{*}{ Sig. } \\
\hline & & & & & & \\
\hline \multirow[t]{2}{*}{1} & (Constant) & 18.417 & 3.981 & & 4.626 & .000 \\
\hline & $\begin{array}{l}\text { AFTER SALES } \\
\text { SERVICE }\end{array}$ & .568 & 107 & .471 & 5.293 & .000 \\
\hline
\end{tabular}

Table 3

Table Coefficients 1

Source: Data Processing Results, 2020

From Table 4.45 it is known that the variable $X$ has a Sig value. amounting to 0,000 . When compared with the $\alpha$ value $(0.000<0.05)$. Thus, the significance and magnitude of Beta (coefficient) of After Sales Service variable path $(X)$ to Value Co-Creation $(Y)$ is $0.778(\rho y X)$ so that the equation is:

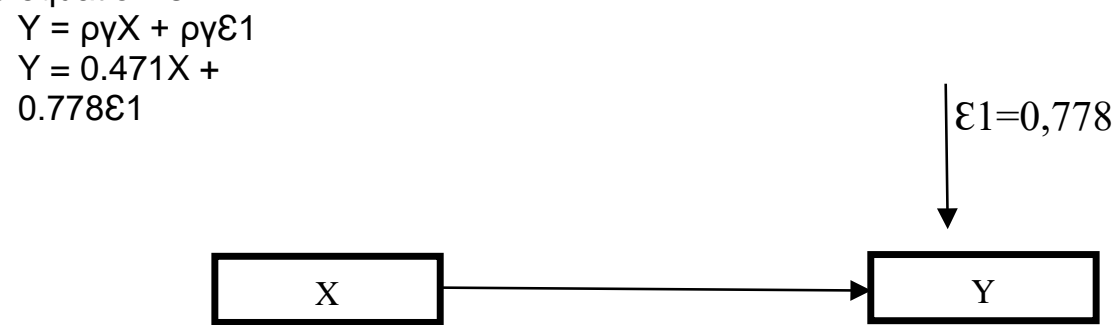

Figure 4

Sub Structural Results-1

Source: Researcher, 2020

ATM Vol 5, No. 1,January $2021: 62-72$ 


\section{Sub Structural-2}

Table 4 Model Summary

Model Summary

\begin{tabular}{|l|c|c|r|c|}
\multicolumn{6}{|c|}{ Model Summary } \\
\hline Model & R & R Square & Adjusted R Square & $\begin{array}{c}\text { Std. Error of the } \\
\text { Estimate }\end{array}$ \\
\hline 1 & $.698^{\circ}$ & .487 & .476 & 5.17978 \\
\hline \multicolumn{2}{|r|}{ a. Predictors: (Constant), VALUE CO-CREATION (Y), AFTER SALES SERVICE } \\
\hline
\end{tabular}

Source: Data Processing Results, 2020

From the Model Summary table data, it is known that the magnitude of $R$ Square $\llbracket(R \rrbracket \wedge$

2 ) is 0.487 . This figure is used to see the magnitude of the influence of the $Y$ and $Z$ variables

by calculating the determinant coefficient (KD) with the following formula:

$\mathrm{KD}=\mathrm{R} 2 \times 100 \% \mathrm{KD}=0.487 \times 100 \%$

$$
\mathrm{KD}=48.7 \%
$$

The amount of the path coefficient for other variables outside the research that affects it can be calculated using the following formula:

$$
\begin{aligned}
\text { P VE1 }= & \sqrt{ } 1-R 2 Y Z \\
= & \sqrt{ } 1-0.487 \\
& =0.513
\end{aligned}
$$

\begin{tabular}{|c|c|c|c|c|c|c|}
\hline \multicolumn{7}{|c|}{ Coefficients $^{a}$} \\
\hline \multirow{2}{*}{\multicolumn{2}{|c|}{ Model }} & \multicolumn{2}{|c|}{$\begin{array}{l}\text { Unstandardized } \\
\text { Coefficients }\end{array}$} & \multirow{2}{*}{$\begin{array}{c}\begin{array}{c}\text { Standardized } \\
\text { Coefficients }\end{array} \\
\text { Beta }\end{array}$} & \multirow[t]{2}{*}{$\mathrm{t}$} & \multirow[t]{2}{*}{ Sig. } \\
\hline & & $\mathrm{B}$ & Std. Error & & & \\
\hline \multirow[t]{3}{*}{1} & (Constant) & 837 & 3.734 & & 224 & .823 \\
\hline & AFTER SALES SERVICE & .368 & .103 & .293 & 3.558 & .001 \\
\hline & $\begin{array}{l}\text { VALUE CO- } \\
\text { CREATION }(\mathrm{Y})\end{array}$ & .530 & .086 & .509 & 6.176 & .000 \\
\hline \multicolumn{7}{|c|}{ a. Dependent Variable: customer LoyALtY } \\
\hline
\end{tabular}

Table 5 Coefficients

Source: Data Processing Results, 2020

From Table 4:46 it is known that the $Y$ variable has a Sig value. amounting to 0,000 . When compared with the $\alpha$ value $(0.000<0.05)$. Thus, $t$ he significance and magnitude of the Beta (coefficient) path of the variable $Y$ to $Z$ is $0.513(\rho z Y)$ so that the equation is:

$$
\begin{aligned}
& Y=\rho z Y+\rho y \varepsilon 1 \\
& Y=0.509 X+0.513 \varepsilon 1
\end{aligned}
$$

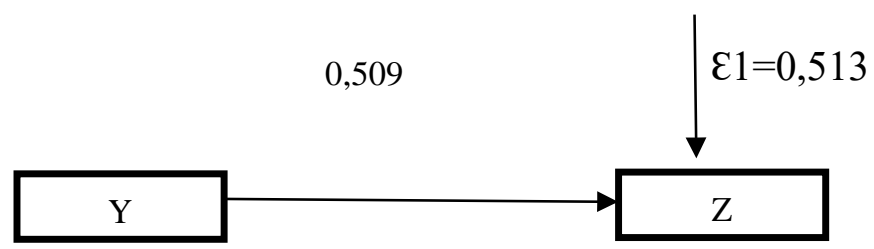

Figure 4.37. Sub Structural Results-2

Source: Researcher, 2020 


\section{Sub Structural-3}

Table 6

Model Summary 3

\begin{tabular}{|l|c|c|c|c|}
\hline \multicolumn{5}{|c|}{ Model Summary } \\
\hline Model & R & R Square & $\begin{array}{c}\text { Adjusted R } \\
\text { Square }\end{array}$ & $\begin{array}{c}\text { Std. Error of } \\
\text { the Estimate }\end{array}$ \\
\hline 1 & $.665^{3}$ & 442 & .430 & 5.19089 \\
\hline $\begin{array}{l}\text { a. Predictors: (Constant), } \\
\text { PURNA }\end{array}$ & \multicolumn{4}{|c|}{ CUSTOMER LOYALTY, AFTER SALES SERVICE } \\
\hline \multicolumn{4}{|l|}{ b. Dependent Variable: VALUE CO-CREATION (Y) } \\
\hline
\end{tabular}

Source: Data Processing Results, 2020

Data from the Model Summary table, it is known that the magnitude of $R$ Square $\llbracket(R \rrbracket \wedge$

2 is 0.442 . This figure is used to see the magnitude of the influence of After Sales Service $X$ and Value Co Creation $Y$ variables on Customer Loyalty $Z$ by calculating the determinant coefficient $(\mathrm{KD})$ with the following formula:

$\mathrm{KD}=\mathrm{R} 2 \times 100 \% \mathrm{KD}=0.442 \times 100 \%$

$\mathrm{KD}=44.2 \%$

This figure means that the influence of After Sales Service variable variable $X$ and Value Co Creation $Y$ on Customer Loyalty $Z$ is $44.2 \%$. Meanwhile, the remaining $55.8 \%$ (10\% - 44.2\%) were influenced by other factors. The amount of the path coefficient for other variables outside the research that affects it can be calculated using the following formula:

$$
\begin{aligned}
P \text { yE2 }= & \sqrt{ } 1-R 2 Z X Y \\
& =\sqrt{ } 1-0,442 \\
& =0.558
\end{aligned}
$$


Table 7 Coefficients $^{\mathrm{a}}$

\begin{tabular}{|c|c|c|c|c|c|c|}
\hline \multicolumn{7}{|c|}{ Coefficients $^{a}$} \\
\hline \multirow{2}{*}{\multicolumn{2}{|c|}{ Model }} & \multicolumn{2}{|c|}{$\begin{array}{l}\text { Unstandardized } \\
\text { Coefficients }\end{array}$} & \multirow{2}{*}{$\begin{array}{c}\begin{array}{c}\text { Standardized } \\
\text { Coefficients }\end{array} \\
\text { Beta }\end{array}$} & \multirow[t]{2}{*}{$t$} & \multirow[t]{2}{*}{ Sig. } \\
\hline & & B & Std. Error & & & \\
\hline \multirow[t]{3}{*}{1} & (Constant) & 12.773 & 3.511 & & 3.638 & .000 \\
\hline & AFTER SALES SERVICE & .212 & .108 & .176 & 1.960 & .053 \\
\hline & CUSTOMER LOYALTY & .532 & .086 & .554 & 6.176 & .000 \\
\hline
\end{tabular}

Source: Data Processing Results, 2020

From the table 4.48 above, the conclusion is that there is a significant influence or contribution from variable $X$ to variable $Z$ and the amount of Beta (path coefficient) of After Sales Service $(X)$ variable on Customer Loyalty $(Z)$ is 0.176 . The Value Co-Creation variable is significant for the variable Customer Loyalty $(Z)$ and the amount of Beta (the path-coefficient variable $Y$ to $Z$ is 0.554 .

$Z=\rho \gamma X+\rho z \gamma+\rho z X+\rho z \varepsilon 2$

The relationship framework for After Sales Service $(X)$ variable to Customer Loyalty $(Z)$ and Value Co Creation $(Y)$ variable to Customer Loyalty $(Z)$ can be made through the following structural equation:

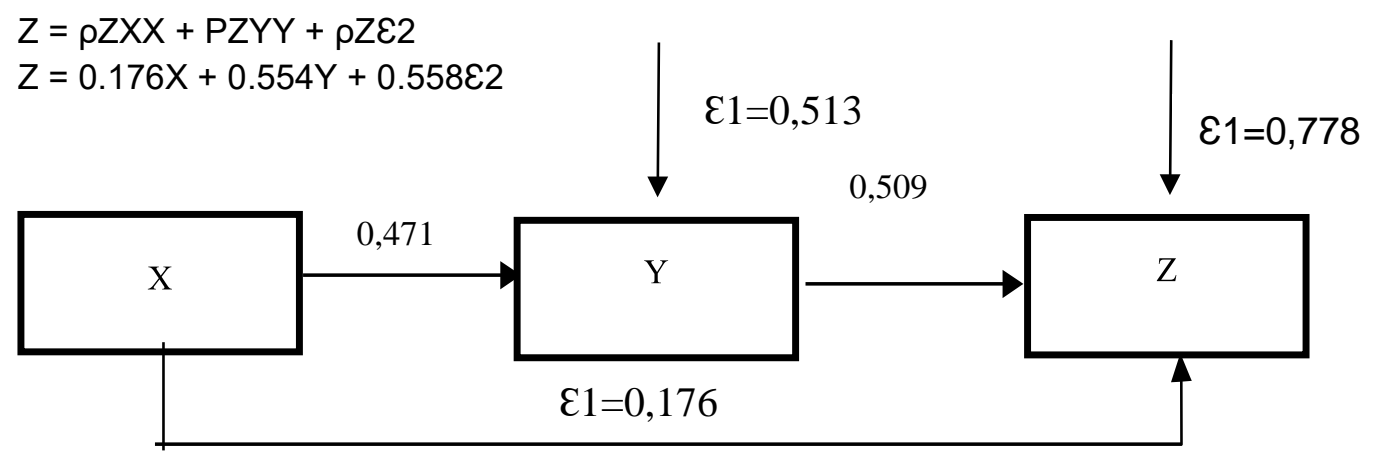

Figure 4.38

Sub Structural Results-3

Source: Researcher, 2020

\section{Hypothesis Test}

1) First Hypothesis

The results show that the sig. $(0.000)<\alpha(0.05)$ and $t$ count $(7.503)>t$ table (1.649) then $\mathrm{H} 0$ is rejected. Thus it can be seen that After Sales Service Partially affects Value Co-Creation.

2) Second Hypothesis

The results show that the sig. $(0.000)<\alpha(0.05)$ and $t$ count $(6.176)>t$ table $(1.66055)$ then $\mathrm{H} 0$ is rejected. Thus it can be seen that Value Co-Creation Partially affects Customer Loyalty.

3) Third Hypothesis

The sobel table states test calculation, it's known that the $t$ value is 3.99862. $t$ table is obtained from the degree of freedom: (nk) or 100-2 of 98 with the Sig. $5 \%$ then obtained t table 1.66055 . Because tcount 3.99862> t table 1.66055, Value Co-Creation can mediate the relationship between After Sales Service and Customer Loyalty.

\section{Conclusion}

Based on the research it can be seen that there are:

The partial effect of after-sales service $(\mathrm{X})$ on Value Co-Creation $(\mathrm{Y})$ is 0.471 or $47.1 \%$. 
Partial effect of Value co-creation $(Y)$ on Customer Loyalty $(Z)$ the value is 0.509 or $50.9 \%$. The simultaneous effect of After Sales Service $(X)$ and Value Co-Creation $(Y)$ on Customer Loyalty $(Z)$ is $0.188(18.8 \%)$ with the single test calculation, it can be seen that t count is 3.99862 , while $\mathrm{t}$ table is 1.66055 then $\mathrm{HO}$ is rejected. This shows that after-sales service has a direct and indirect effect on consumen loyalty by $18.8 \%$, while the remaining $100-18.8 \%=81.2 \%$ is a contribution from other variables $(£)$ which are not examined in this study. Thus proving that After Sales Service $(X)$ and Value Co- Creation $(Y)$ to Customer Loyalty $(Z)$ together contribute simultaneously. Thus, it proves that After Sales Service $(X)$ to Customer Loyalty $(Z)$ through Value Co-Creation $(\mathrm{Y})$ together contribute simultaneously. Where this research was taken by (Ashfaq, 2019) [19] which states that After Sales Service and Customer Loyalty have a significant effect on After-Sales Service on Customer Loyalty, whereas (Cossío-silva \& Revillacamacho, 2016) [21] which states that Value Co Creation on Customer Loyalty has a significant effect and simultaneously to customer satisfaction.

The company in this case the management must be sensitive to several things that can improve after-sales service. This is based on the results of the research showing that after-sales service has an effect either directly or indirectly on customer loyalty to iPhone smartphone users in the online community. With the improvement of several things that affect after-sales service, it will have a direct positive influence on customer loyalty. Management also needs to pay attention to the benefits of value co creation, given its enormous influence on customer loyalty.

The next researcher is expected to examine other variables that have not been studied but have an effect on customer loyalty. So that we can find out whether other variables affect it or not because it is seen from the results as much as $81.2 \%$ is the contribution of other variables (£) which were not examined in this study.

\section{References}

[1] D. A. E. Putra, "SMARTPHONE SEBAGAI GAYA HIDUP (Studi Deskriptif Tentang Penggunaan Smartphone Sebagai Gaya Hidup Mahasiswa FISIP USU)," pp. 1-11, 2015.

[2] Pahrul, "DAMPAK PENGGUNAAN SMARTPHONE (STUDI PERILAKU SOSIAL SISWA SMA NEGERI KECIL PULAU KULAMBINGKABUPATEN PANGKEP)," 2018.

[3] I. M. Wardana, "PENGARUH EKUITAS MEREK TERHADAP KEPUTUSAN PEMBELIAN IPHONE DI DENPASAR,” E-Jurnal Manaj. Unud, vol. 4, no. 4, pp. 832-848, 2015.

[4] Bagas Sunu Pratama, A. Fathoni, and L. B. Hashiolan, "Analisis pengaruh desain produk, brand image, fitur, kualitas produk, dan harga terhadap keputusan pembelian hp samsung," J. Ilmu Manaj., 2017.

[5] F. Pureklolong, "Pengaruh Kepuasan Terhadap Loyalitas Konsumen," 2017.

[6] S. S. Simanullang, "Analisis Pengaruh Kualitas Pelayanan Terhadap Loyalitas Konsumen Jasa Transportasi Online Dengan Kepuasan Konsumen Sebagai Variabel Moderating (Studi Kasus Mahasiswa Fakultas Ekonomi dan Bisnis Islam Jurusan Ekonomi Islam 2014-2016 UIN-SU)," 2018.

[7] A. Irnandha, "Pengaruh Kualitas Layanan terhadap Loyalitas Pelanggan yang dimediasi oleh Kepuasan Pelanggan," 2016.

[8] T. M. S. S. Wibowo, "DAMPAK KUALITAS PRODUK DAN LAYANAN PURNA JUAL TERHADAP LOYALITAS MELALUI KEPUASAN PELANGGAN Teguh Wibowo dan Muchsin S Shihab," pp. 1-18, 2016.

[9] S. Purwanto, "PENGARUH EKUITAS MEREK, PELAYANAN PURNA JUAL DAN KUALITAS PRODUK TERHADAP MINAT PEMBELIAN LAPTOP ASUS," 2018.

[10] R. A. Asnandar Simanjuntak, Mohammad Iqbal, "KEPUTUSAN PEMBELIAN ( Survei pada Konsumen Sepeda Motor Merek Honda," vol. 55, no. 3, pp. 110-117, 2018.

[11] Y. Wijaya, "PENGARUH AFTER SALES SERVICE TERHADAP REPURCHASE INTENTION MELALUI CUSTOMER SATISFACTION SEBAGAI VARIABEL INTERVENING DI PT DAMAI SEJAHTERA ABADI (UFO ELEKTRONIKA) SURABAYA," vol. 7, no. 1, 2019.

[12] R. H. T. S. S. Iriani, "PENGARUH BRAND EXTENSION, KUALITAS PRODUK, DAN LAYANAN PURNA JUAL TERHADAP KEPUTUSAN PEMBELIAN ASUS SMARTPHONE Rahmawati," 2015.

[13] O. B. Maduka, "Effects of Customer Value Co-Creation on Customer Loyalty in the Nigerian Service Industry," vol. 11, no. 12, pp. 77-82, 2016.

[14] J. Kim and H. Choi, "VALUE CO-CREATION THROUGH SOCIAL MEDIA: A CASE 
STUDY OF A START-UP COMPANY," vol. 20, no. 1, pp. 1-19, 2019.

[15] P. Coetzee, "The relationship between value co-creation and customer perceived value," no. November, 2016.

[16] M. Galvagno, "Theory of value co-creation : a systematic literature review," no. September, 2015.

[17] S. Kiswati, "Studi tentang sikap konsumen atas merek tolak angin," 2010.

[18] G. M. P. Eduardo Luiz Braun and M. A. S. and M. Borchardt, "Value co-creation in maintenance services: case study in the mechanical industry," 2014.

[19] M. Ashfaq, "After Sales Service, Customer Satisfaction and Loyalty in Telecom Sector Journal of Applied Structural Equation Modeling AFTER SALES SERVICE , CUSTOMER SATISFACTION AND LOYALTY IN TELECOM SECTOR," no. May, 2019.

[20] S. Zuhdi, "PENGARUH PELAYANAN PURNA JUAL TERHADAP LOYALITAS PELANGGAN Studi kasus pada PT . Astra Internasional Tbk cabang Bogor EFFECT ON AFTERMARKET SERVICE CUSTOMER LOYALTY case studies on i ...," no. November 2012, 2018.

[21] F. Cossío-silva and M.-ángeles Revilla-camacho, "Value co-creation and customer loyalty 认s," J. Bus. Res., vol. 69, no. 5, pp. 1621-1625, 2016. 